\title{
Um dia triste para a ciência, a história e a cultura brasileiras
}

I ${ }^{1}$ Kenneth R. de Camargo Jr. I ${ }^{1}$ Instituto de Medicina Social, Universidade do Estado do Rio de Janeiro. Rio de Janeiro-RJ, Brasil (kenneth@uerj.br).
ORCID: 0000-0003-3606-5853

DOI: http://dx.doi.org/10.1590/S0103-73312018280301

Segunda-feira, 3 de setembro de 2018, manhã.

Da passarela que dá acesso ao Instituto de Medicina Social, no campus Maracanã da UERJ, se divisa uma coluna de fumaça que se ergue do Palácio Imperial, sede do Museu Nacional. Fragmentos chamuscados de manuscritos foram vistos no campus, muito provavelmente traços do incêndio trazidos pelo vento, testemunhas mudas da catástrofe que se iniciara na véspera.

Muito já se escreveu (e vai se escrever) sobre a perda incomensurável para a ciência e a cultura do nosso país, e como esse episódio é emblemático do descaso com que a ciência, a educação e a cultura vêm sendo tratadas no Brasil.

Não desejamos reiterar o que já foi dito, para além de nos solidarizarmos com nossos colegas do Museu Nacional e dos programas de ensino e pesquisa da Universidade Federal do Rio de Janeiro (UFRJ) lá sediados, mas não podemos nos furtar a fazer dois registros.

Em primeiro lugar, o visceral repúdio a qualquer tentativa de responsabilizar as vítimas - professores e funcionários da UFRJ - pela fragilidade do prédio frente ao incêndio. As tentativas de culpar quem sempre lutou pela sobrevivência da instituição são um eco perverso da trágica morte do então reitor da Universidade Federal de Santa Catarina (UFSC), Luiz Carlos Cancellier de Olivo, vítima de indesculpável abuso de poder. 
Em segundo lugar, não se pode fechar os olhos para as consequências de uma política econômica não apenas equivocada, mas que favorece o rentismo, alimenta a desigualdade e a concentração de renda, e asfixia políticas sociais essenciais para a educação, a saúde e o desenvolvimento científico e tecnológico do país, na contramão do que deveriam ser as prioridades de um governo comprometido com seu povo (OLIVEIRA; DWECK; ROSSI, 2018).

No mais, apesar de perdas irreparáveis, o Museu Nacional e as atividades ali sediadas continuam. Professores, funcionários e alunos já começaram o esforço da reconstrução possível.

Contem conosco.

\section{Referência}

OLIVEIRA, A. L. M.; DWECK, E.; ROSSI, P. (Orgs.). Economia para poucos - Impactos sociais da austeridade e alternativas para o Brasil. São Paulo: Ed. Autonomia Literária, 2018. 